\title{
Protecting health care workers from COVID-19: implementing a training programme on personal protective equipment in Pakistan
}

Assad Hafeez, ${ }^{1}$ Ramesh Kumar, ${ }^{1}$ Ikhlaq Ahmed ${ }^{1}$ and Zaeem ul Haq ${ }^{2}$

${ }^{1}$ Health Services Academy, Islamabad, Pakistan. ${ }^{2}$ Ministry of National Health Services Regulation and Coordination, Islamabad, Pakistan (Correspondence to: Ramesh Kumar: drramesh1978@gmail.com).

\begin{abstract}
Background: Pakistan's Ministry of National Health Services, Regulations and Coordination, with support from the World Health Organization, developed and implemented the "We Care" programme to protect frontline health care workers engaged in the coronavirus disease 2019 (COVID-19) response.
\end{abstract}

Aims: This paper reports on the training part of the programme, which aimed to train 100000 frontline health care workers on the proper use of personal protective equipment (PPE) and on the lessons learnt from implementation of the training.

Methods: A team of experts developed the curriculum and its accompanying material. Initial training was given to deans of all participating institutions and to master trainers from each university. Staff of all public and private hospitals enrolled in the training and other frontline health care workers were invited to register individually. Four types of educational material were produced and used a guidance booklet, a training video, a set of PowerPoint presentations to explain the PPE and their use, and a poster.

Results: A total of 2000 training sessions were conducted across the country from May to December 2020 and 100000 frontline health care workers were trained on the use of PPE. Of those trained, $25 \%$ were doctors, $35 \%$ were nurses and paramedics, and $40 \%$ were allied health staff, with an almost equal gender distribution.

Conclusions: With limited resources and over a short period, the We Care programme trained a large number of frontline health care workers, which enhanced their safety and reduced the irrational use of PPE.

Keywords: COVID-19, capacity-building, health personnel, personal protective equipment, PPE, Pakistan

Citation: Hafeez A; Kumar R; Ahmed I; Haq Z. Protecting health care workers from COVID-19: implementing a training programme on personal protective equipment in Pakistan. East Mediterr Health J. 2022; 28(2):163-168. https://doi.org/10.26719/emhj.21.064

Received: 21/03/21; accepted: 15/06/21

Copyright (c) World Health Organization (WHO) 2022. Open Access. Some rights reserved. This work is available under the CC BY-NC-SA 3.0 IGO license (https://creativecommons.org/licenses/by-nc-sa/3.o/igo).

\section{Introduction}

The recent outbreak of respiratory illness caused by severe acute respiratory syndrome coronavirus 2 (SARSCoV-2) is recognized as a serious public health threat (1). The first case of coronavirus disease 2019 (COVID-19) was reported in Wuhan city in China in December 2019. The virus has been confirmed as a fatal zoonotic coronavirus species that probably travels from animals to humans, and results in sustained human-to-human transmission through droplets, contact and fomites (2-6). In Pakistan, the first case of COVID-19 was reported in February 2020 and by April 2020, a total of 15759 cases had been reported. The province most affected by this virus was Punjab, with 6061 COVID-19 cases, followed by Sindh with 5695 (7).

Frontline health care workers, including doctors, nurses, paramedics, and allied staff are at increased risk of COVID-19 infection during routine activities because they manage COVID-19 and non-COVID-19 patients coming to the health facility. Protecting frontline health care workers from infection is an essential part of the outbreak response and using personal protective equipment (PPE) is essential in providing protection.
PPE includes gloves, medical masks, goggles or face shields, as well as gowns, respirators (i.e. N95 or FFP2 standard or equivalent) and aprons used for specific procedures (8).

However, data show that many frontline health workers were unaware of the appropriate use of PPE against the new virus (9) while attending to dealing with patients in emergency rooms, intensive care units, laboratories, and isolation wards and treatment units especially set up for the COVID-19 patients. Therefore, protecting these frontline health workers was essential. Studies in an early phase of the pandemic in China had shown that health workers who followed standard operating procedures for infection control were safe from COVID-19 despite handling COVID-19 patients (9).

In addition to being vulnerable to contracting COVID-19, frontline health workers experience mental stress as a result of managing COVID-19 patients. An important factor causing this mental stress is their perceived vulnerability to infection. Providing standardized training on the use of PPE among health care workers would not only reduce their risk of contracting infection, but would also reduce anxiety, caused by their vulnerability to infection. This training could be 
an important pillar of a government's response strategy and would reduce anxiety and undue criticism during an infectious disease outbreak (10). Proper training on the use of PPE among health workers and organizational support could reduce anxiety among these workers and improve their confidence in handling patients during the pandemic (11).

The Government of Pakistan, its Ministry of National Health Services, Regulation and Coordination, and the National Command and Operation Centre for COVID-19 organized a knowledge and skill-building programme (We Care programme) on the use of PPE for all tiers of frontline health care workers, including doctors, nurses, paramedics and allied health staff (12). The We Care programme aimed at making health workers aware of the role of PPE in protecting them and their responsibility to wear the proper PPE based on the risk of infection in the environment they are working in. Making arrangements to address the mental health issues of frontline health workers through dedicated helplines and continuous morale-boosting campaigns in the media were also part of the We Care programme (13). This paper reports on the PPE training part of the We Care programme and lessons learnt from implementation.

\section{Methods}

\section{Training programme}

The objective of the We Care programme was to train 100000 frontline health care workers on the proper use of PPE, based on guidelines on how, where and when to use a specific type of PPE, agreed by the Ministry of National Health Services, Regulation and Coordination, and the provincial health departments.

\section{Programme design}

The Health Services Academy, an established national in-service training, research and academic institution attached to the Ministry of National Health Services, Regulation and Coordination, was tasked to design and implement this programme. The Health Services Academy collaborated with six universities in the federal capital and all provinces (Punjab, Sindh, Khyber Pakhtunkhwa, Balochistan and Gilgit Baltistan, in order of population size) to disseminate this training across the country. A team of experts in designing and delivering health care training developed the curriculum and its accompanying material. Initial training was held for the deans of all participating institutions as well as to master trainers from each university. All the hospitals in both public and private sectors in all the provinces and regions were advised to enrol their staff in the training. Through newspaper advertisements, frontline health care workers were invited to register individually. The Health Services Academy maintained a list of registered participants and those who completed the training, and supported activities through weekly meetings with respective trainers and focal points.

\section{Training material}

Four types of educational materials were produced: a guidance booklet, a training video, a set of PowerPoint presentations to explain the PPE and their use, and a newspaper advertisement (poster size) that frontline health workers could put on a wall in their offices or work settings (13). The guidance booklet was a reference document for each participant and contained details of PPE that should be used according to the type of setting, personnel and the type of activity they performed. The training video was a five-minute video demonstrating the different types of PPE and how to put on and remove each type. The presentation slides explained the national guidelines for the safety of health care workers, and the use of PPE in different situations (14). The newspaper advertisement was a colour poster outlining what type of PPE should be used by which health workers and in what specific settings. The advertisement was published in national newspapers and on social media. It also included a link for frontline health care workers to register for the We Care training programme.

\section{Cascaded training}

The team of experts first trained 10 master trainers in each of the provinces. The master trainers then delivered the training to other frontline workers through live online sessions. They used PowerPoint slides and a training video to explain PPE and demonstrate skills in using PPE. The participants were guided to make use of reference materials, i.e. guidance booklet and the PPE poster during their practice. Allied staff (ward boys and janitorial staff) who did not have access to digital technology or had language difficulties, were given in-class training in the local language while observing physical distancing and other preventive measures.

During training, the participants were given detailed information about the rational use of PPE in seven specific situations i.e. in-patient facilities, outpatient facilities, points of entry, ambulance transfer, sample collection, in laboratory facilities and in the community (15). Each scenario was explained with the help of a pictorial chart that described the setting, target person or patients, activity and PPE required in that particular situation. For example, the frontline health workers who provide direct care to COVID-19 patients were informed that they needed N95 masks, gloves, gowns and eye protection, whereas ward cleaners in the same setting were informed that they needed medical masks, gloves, gowns, eye protection and shoe covers (16).

\section{Motivation}

To develop an overall environment of social support and motivation, several public service messages were developed and broadcast on television, radio and social media. These motivational messages showcased the dedicated efforts of frontline health care workers to treat and save the lives of COVID-19 patients in local hospitals across the country. Preventive measures for the community were emphasized in these messages, including hand hy- 
giene, respiratory hygiene, use of masks and social distancing (13).

\section{Results}

The We Care training activities for frontline health workers were conducted in all four provinces and two regions of Pakistan. With an average of 50 participants in a session, a total of 2000 sessions were conducted from May to December 2020 for 100000 frontline health care workers across the country. Although we initially aimed to complete the training programme within eight months, the roll-out had some challenges and the desired number was reached in six months. The duration of each session was about one hour, which comprised of a PowerPoint presentation, video demonstration, and a question and answer session. A certificate of participation was given to all those who completed the training.

A total of 100000 frontline health care workers were trained from all the provinces and administrative areas of Pakistan (Figure 1) during the project. Of those trained, $25 \%$ were doctors, $35 \%$ were nurses and paramedics and $40 \%$ were allied health staff, with an almost equal gender distribution.

The training sessions were organized simultaneously in all provinces and regions. The distribution of frontline health care workers completing the trainings in the provinces and regions were: Punjab 30000 , Khyber Pakhtunkhwa 25 000, Sindh 20 000, Baluchistan 10 000, Gilgit Baltistan 2000, and Islamabad Capital Territory and Azad Jammu and Kashmir 13000 (Figure 2).

\section{Discussion}

The We Care programme trained 100000 frontline health care workers from all provinces and areas of the country, with an equal number of men and women. All types of frontline health care workers, including doctors, nurses, paramedics, and allied health staff, were trained in the appropriate selection and use of PPE. With limited resources and in a short period, the We Care programme trained a large number of frontline health care workers. This training has enhanced the safety of frontline health

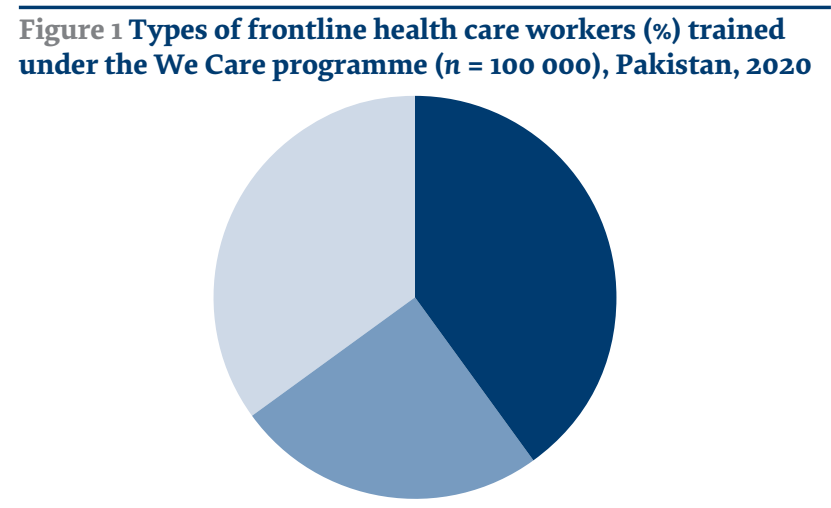

Allied health workers Nurses and paramedicas

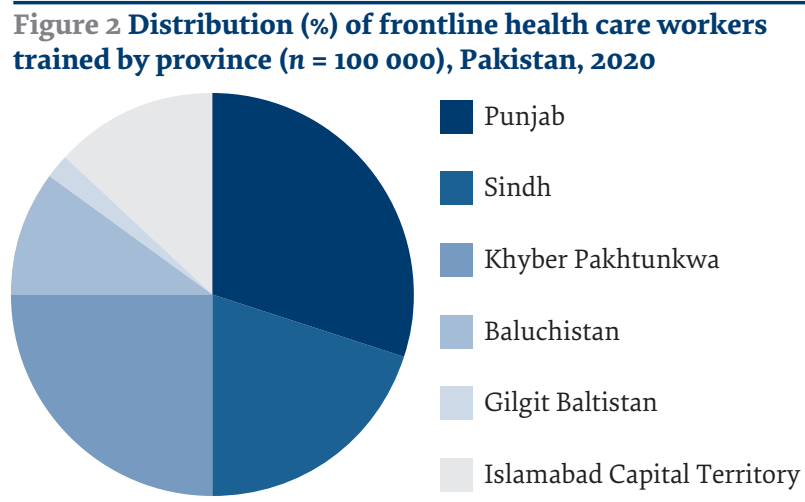

care workers and reduced the irrational use of PPE at a time when the availability and supply of these lifesaving resources are limited (17).

The training was implemented because studies had indicated the lack of rational use of PPE among frontline health care workers in Pakistan: compliance with the use of PPE was low and PPE items were being reused (18). The recommendation was that health workers should be given sufficient training on choice and appropriate use of PPE (19). Non-availability of PPE, improper guidance on the use of PPE, rapidly changing standard operating procedures and lack of regular testing among health workers had a great effect on adherence to infection control practices among frontline health care workers. This situation ultimately led to high infection rates during the pandemic (20). Appropriate use and provision of PPE for frontline health care workers is the recommended approach for the prevention of COVID-19 infection among health workers (21).

Acute shortages of PPE and inappropriate use on the part of health workers was frequently reported in the early phases of the current pandemic $(10,13,14)$. Health facilities faced acute shortage of supplies and the limited availability of protective equipment for health workers led to criticism of governments and demotivation among the health workers (15). Training of health professionals was greatly needed to update their skills and knowledge. Moreover, appropriate use of PPE could protect health care workers from COVID-19 $(9,12,13,21)$.

Through a hybrid model of both online and in-class training of frontline health care workers, the We Care programme proved that such capacity-building can be achieved even with limited time and resources, and during a lockdown situation. Examination of data from the successive waves of COVID-19 in Pakistan show that frontline health care workers adopted the rational use of PPE leading to a decrease in daily new infections among these workers during the two comparable peaks from 166 COVID-19 cases a day in June 2020 to 36 a day in May 2021 (22). The We Care programme is a good example of pragmatic decisions and their implementation and it provides evidence for policy-makers to replicate similar sessions in resource-constrained situations. In the United Kingdom of Great Britain and Northern Ireland, during 
the COVID-19 pandemic, frontline health care workers were more confident during their handling of patients when they had protective measures (13).

Implementing a quick training programme for 100000 frontline health care workers of different types to address a capacity gap in the overall emergency response is a significant achievement. A few limitations, however, must be mentioned. We could not develop a robust monitoring and evaluation component that could use frameworks such as the Kirkpatrick model (23) during the learning or practice stages. Similarly, the impact of the components of the programme to boost morale among frontline health care workers and raise a sense of responsibility among the community could not be evaluated.

Studies elsewhere have shown the effectiveness of such training programmes. For example, in China, none of the 426 health care workers participating in a similar training programme developed COVID-19 (17,18). There are multiple types of PPE and this can cause error in selection and usage, whereas training significantly reduces incorrect use and increases the protection of frontline health care workers from infection $(18,20)$.

\section{Conclusion}

Training frontline health care workers proved beneficial for the rational use of PPE and possibly helped reduce new infections among the frontline health care workers. By extension, the training helped in managing the limited supply of PPE during the lockdown. Organizational support and a conducive social environment may also have improved the motivation of frontline health care workers and their behaviours related to infection prevention and control. We recommend refresher PPE training and the inclusion of such training in the regular curriculum of health professionals. We also recommend that the impact of such training be evaluated and appropriate budgets allocated for such training in the annual development provincial health plans.

\section{Acknowledgement}

We thank all the training facilitators who contributed to the sessions. We also thank the WHO Pakistan Office for providing funding for this training.

Funding: WHO Pakistan Office.

Competing interests: None declared.

\section{Protection des agents de santé contre la COVID-19 : mise en œuvre d'un programme de formation sur les équipements de protection individuelle au Pakistan}

\section{Résumé}

Contexte: Avec le soutien de l'Organisation mondiale de la Santé, le ministère pakistanais des Services de Santé nationaux, de la réglementation et de la coordination a élaboré et mis en œuvre le programme «We Care » pour protéger les agents de santé de première ligne engagés dans la riposte à la maladie à coronavirus 2019 (COVID-19).

Objectifs: Le présent article rend compte de la partie du programme consacrée à la formation, qui visait à former 100000 agents de santé de première ligne à l'utilisation correcte des équipements de protection individuelle (EPI) et de les informer des enseignements tirés de la mise en œuvre de cette formation.

Méthodes : Une équipe d'experts a élaboré le programme et les matériels qui l'accompagnaient. Une formation initiale a été dispensée aux doyens de toutes les institutions participantes et aux maîtres formateurs principaux de chaque université. Le personnel de tous les hôpitaux publics et privés participant à la formation et d'autres agents de santé de première ligne ont été invités à s'inscrire individuellement. Quatre types de matériels éducatifs ont été produits et utilisés : une brochure d'orientation, une vidéo de formation, une série de présentations PowerPoint pour expliquer l'EPI et son utilisation, et une affiche.

Résultats: Au total, 2000 sessions de formation ont été organisées dans tout le pays entre mai et décembre 2020 et 100000 agents de santé de première ligne ont été formés à l'utilisation des EPI. Parmi les personnes formées, $25 \%$ étaient médecins, $35 \%$ étaient des personnels infirmiers et paramédicaux et $40 \%$ étaient des personnels de santé auxiliaires, avec une répartition quasiment égale entre les sexes.

Conclusions : Avec des ressources limitées et en peu de temps, le programme «We Care » a permis de former un grand nombre d'agents de santé de première ligne, ce qui a amélioré leur sécurité et réduit l'utilisation irrationnelle des EPI. 


$$
\begin{aligned}
& \text { حماية العاملين في بجال الرعاية الصحية من مرض كوفيد-19: تنفيذ برنامج تدريبي على معدات الوقاية الشخصية، } \\
& \text { باكستان } \\
& \text { أسعد حفيظ، راميش كومار، أخلاق أحم، زعيم الحق } \\
& \text { الخلاصة }
\end{aligned}
$$

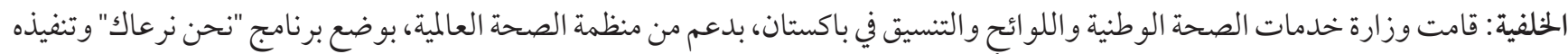

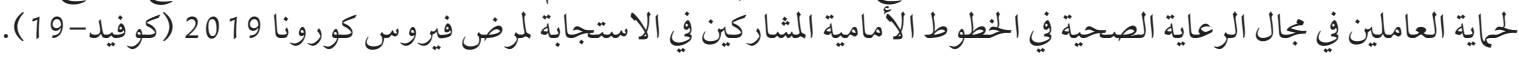

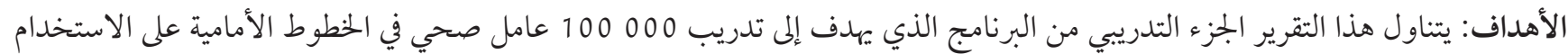

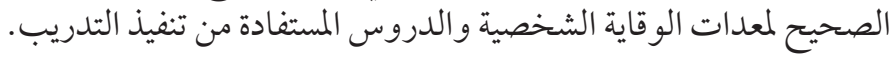

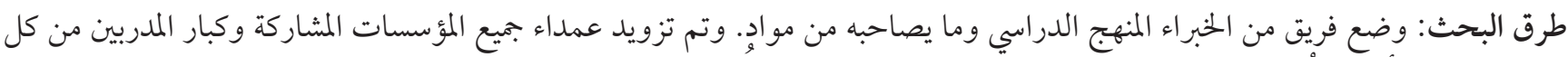

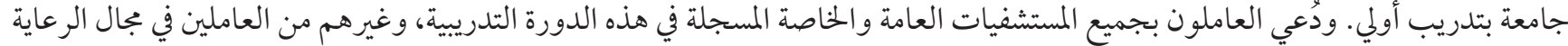

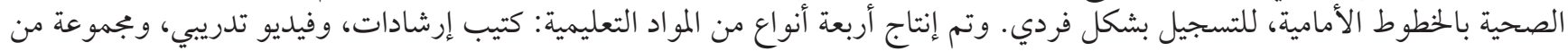

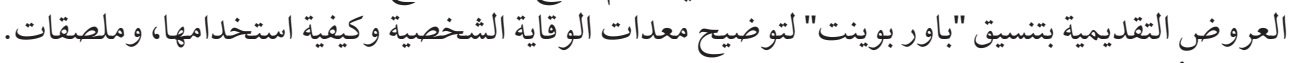

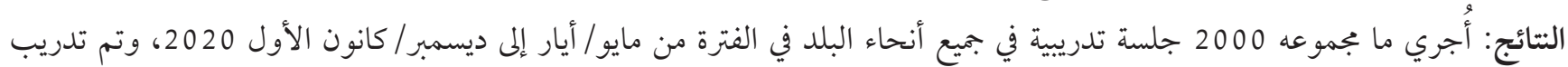

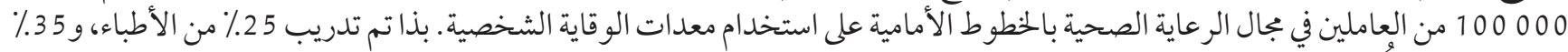

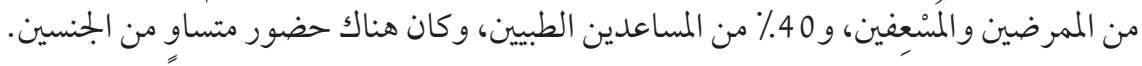

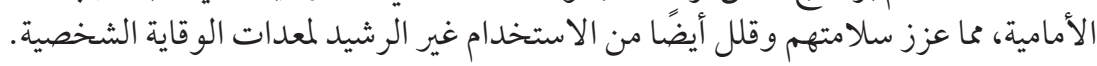

\section{References}

1. COVID 19 and animals [Internet]. Atlanta, GA: Center for Disease Control and Prevention; 2021 (https://www.cdc.gov/coronavie rus/2019-ncov/daily-life-coping/animals.html, accessed 30 April 2021).

2. Lu R, Zhao X, Li J, Niu P, Yang B, Wu H, et al. Genomic characterisation and epidemiology of 2019 novel coronavirus: implications for virus origins and receptor binding. Lancet. 2020;395(10224):565-74. https://doi.org/10.1016/So140-6736(20)30251-8

3. Guo YR, Cao QD, Hong ZS, Tan YY, Chen SD, Jin HJ, et al. The origin, transmission and clinical therapies on coronavirus disease 2019 (COVID-19) outbreak - an update on the status. Military Med Res. 2020;7(1):11. https://doi.org/10.1186/s40779-020-00240-0

4. Banerjee A, Kulcsar K, Misra V, Frieman M, Mossman K. Bats and coronaviruses. Viruses. 2019;11(1):E41. https://doi.org/10.3390/ v11010041

5. Giovanetti M, Benvenuto D, Angeletti S, Ciccozzi M. The first two cases of 2019-nCoV in Italy: where they come from? J Med Virol. 2020;92(5):518-21. https://doi.org/10.1002/jmv.25699

6. COVID-19 data tracker. United States COVID-19 cases, deaths, and laboratory testing (NAATs) by state, territory, and jurisdiction [Internet]. Atlanta, GA: Centers for Disease Control and Prevention; 2020 (https://covid.cdc.gov/covid-data-tracker/\#cases_casesa per1ooklast7days, accessed 30 April 2021).

7. Rolling updates on coronavirus disease (COVID-19) [Internet]. Geneva: World Health Organization; 2021 (https://www.who.int/ emergencies/diseases/novel-coronavirus-2019/events-as-they-happen, accessed 2 January 2021).

8. Rational use of personal protective equipment for coronavirus disease 2019 (COVID-19). Interim guidance, 27 February 2020. Geneva: World Health Organization; 2020 (https://apps.who.int/iris/handle/10665/331215, accessed 5 May 2021).

9. Lai X, Wang M, Qin C, Tan L, Ran L, Chen D, et al. Coronavirus disease 2019 (COVID-2019) infection among health care workers and implications for prevention measures in a tertiary hospital in Wuhan, China. JAMA Netw Open. 2020;3(5):e209666 https:// doi.org/10.1001/jamanetworkopen.2020.9666

10. Karlsson U, Fraenkel CJ. Complete protection from COVID-19 is possible for health workers. BMJ. 2020;370:m2641. https://doi. org/10.1136/bmj.m2641

11. Wu PE, Styra R, Gold WL. Mitigating the psychological effects of COVID-19 on health care workers. CMAJ. 2020;192(17):E459-60. https://doi.org/10.1503/cmaj.200519.

12. National Command and Operation Center (NCOC) [website]. Government of Pakistan; 2020 (https://ncoc.gov.pk/, accessed 25 August 2021).

13. We Care [webpage]. Ministry of National Health Services Regulation and Coordination; 2021 (https://wecare.nhsrc.gov.pk, accessed 25 August 2021).

14. Guidelines. COVID-19 health advisory platform [webpage]. Government of Pakistan; 2020. (https://covid.gov.pk/guideline, accessed 25 August 2021). 
15. National Institute of Health and World Health Organization. National guidelines COVID-19 \& PPE: guidance on rational selection \& use of personal protective equipment. Islamabad: National Institute of Health; 2020 (https://covid.gov.pk/new_guidelines/ 01June2020_20200509-Guidance_on_selection_and_use_of_PPE.pdf, accessed 25 August 2021).

16. Schwartz J, King C, Yen M. Protecting health care workers during the COVID-19 coronavirus outbreak - lessons from Taiwan's severe acute respiratory syndrome response. Clin Infect Dis. 2020;71(15):858-60. https://doi.org/10.1093/cid/ciaa255

17. Chughtai AA, Khan W. Use of personal protective equipment to protect against respiratory infections in Pakistan: a systematic review. J Infect Public Health. 2019;12(4):522-7. https://doi.org/10.1016/j.jiph.2019.01.064

18. Balachandar V, Mahalaxmi I, Kaavya J, Vivekanandhan G, Ajithkumar S, Arul N, et al. COVID-19: emerging protective measures. Eur Rev Med Pharmacol Sci. 2020;24(6):3422-5. https://doi.org/10.26355/eurrev_202003_20713

19. Vindrola-Padros C, Andrews L, Dowrick A, Djellouli N, Fillmore H, Gonzalez EB, et al. Perceptions and experiences of healthcare workers during the COVID-19 pandemic in the UK. BMJ Open. 2020;10(11):e040503. https://doi.org/10.1136/ bmjopen-2020-040503

20. Houghton C, Meskell P, Delaney H, Smalle M, Glenton C, Booth A, et al. Barriers and facilitators to healthcare workers' adherence with infection prevention and control (IPC) guidelines for respiratory infectious diseases: a rapid qualitative evidence synthesis. Cochrane Database Syst Rev. 2020;4(4):CDo13582. https://doi.org/10.1002/14651858.CDo13582

21. Shafaq K, Malik J. How local government can strengthen Pakistan's fight against COVID-19. Democracy Reporting International. 16 April 2020 (https://beta.democracy-reporting.org/en/office/pakistan/publications/how-local-government-can-strengthenpakistans-fight-against-covid-19, accessed 25 April 2021).

22. Haq Z, Mirza Z, Oyewale TO, Sultan F. Leaving no one behind: Pakistan's risk communication and community engagement during COVID-19. J Glob Health 2021;11:03091. https://doi.org/10.7189/jogh.11.03091

23. Reid B. A critical analysis of evaluation practice: the Kirkpatrick model and the principle of beneficence. Eval Program Plann. 2004;27(3):341-7. https://doi.org/10.1016/j.evalprogplan.2004.04.011 